\title{
Interrogating the Theological Argument for the Reality of God within African Religious Milieu
}

\author{
Mepaiyeda, Solomon Makanjuola \\ Department of Religious Studies, University of Ibadan \\ Ibadan, Nigeria \\ E-mail: mepaiyedas@yahoo.com
}

Received: October 1, 2013

Accepted: February 28, 2014 Published: February 26,

2014

doi:10.5296/iss.v2i1.5193

URL: http://dx.doi.org/10.5296/iss.v2i1.5193

\begin{abstract}
Empirical philosophers, down the ages have argued against the existence of God, employing the use of reason as a premise for establishing their argument. This exercise resulted in atheism - the belief that there is no God. While some atheists maintain that God never existed in the past, there are others who contend that he existed but is now dead. Hence, Anselm's theism and other arguments for God's existence pervaded the academic spectrum.

This paper, therefore, establishes the manifestation of theistic arguments within the religious context in Africa. Furthermore, the paper concludes by debunking the misrepresentation of African ideas of God whom some sit-at-home writers described as Deus absconditus or Deus remotus.
\end{abstract}

Keywords: atheism, Anselm's Argument, concept of God, African religion 


\section{Introduction}

Since the Gnostic cosmological idea which attributed the creation of the evil world to a demiurge (Oshitelu, 2002: 63), the Marcionistic concept of dual God (Boer, 1976: 60), the anthropological approach of Ludwig Feuerbach which posited that 'god is no other than the projected image of human nature (Omoregbe, 1993: 117) which Sigmund called 'childhood neurosis'; and of course the 'death of God' theory popularized by Nietzche (Omoregbe, 123) and his allies, the reality of God has not only been the concern of academic circle but people of other fields in the society. In reaction to these postulations and theories, Christian thinkers and apologists did not consider the atheists and agnostics as fools as suggested by legendary David- who maintained in his writings that God's existence is self-evident, therefore should not even be doubted (Ps 14v1); rather, they formulated theories which are normally classified as a priori and a posteriori. Thus, theism which is central to monotheistic religions such as Judaism, Christianity, Islam and African Religion, is a systematic argument meant to establish the existence of God by way of proving it to atheists and agnostics, and at the same time re-affirming it for the benefit of the believers. In this religious concept, God is viewed as both transcendent and immanent, a being distinct from his creation though manifesting himself through it, caring for and communicating with mankind and infinitely worthy of human worship and obedience.

\section{Theistic Arguments}

In the ancient and the medieval times, theism remained an unchallenged phenomenon because at these periods, Europe was seen as a single community under the dual headship of Pope and Emperor (Southgate, 1938: XV). Though the Emperor exercised political power in the Holy Roman Empire, he was also thought of possessing supreme authority in spiritual matters throughout the Christian world. Therefore, at this early period, the authority of the church and its dogma remained unquestioned. This situation made it possible for the popularization of many theological theories to prove the reality of God. These included the cosmological, ontological, teleological, moral arguments as well as argument from truth.

However, for an in-depth study of theism within the space available to this work, discussion shall be limited to the ontological argument. Ontological argument which is referred to as "a priori argument" was propounded by the most outstanding theologian of the eleventh century, St. Anselm. The word "Ontology" is derived from two Greek words, "Ontos" and "Logos" which means the "science of being". It involves the deity and his existence. Its Latin equivalence Ontologia refers to the branch of metaphysics that studies the nature of existence or being as such.

In his proslogion, Anselm says: "God is a being than which nothing greater can be conceived". By 'greater', Anselm means a more perfect being. In addition, he avers that something which exists only in the mind is distinct from something which exists both in the mind and in reality. Putting the two steps to gether he says, "If God does not exist (that is, if he exists only in the mind but not in reality), it is possible to conceive of a more perfect being than the most perfect being". Since that is an impossible contradiction, we must accept the alternative, that is, the most perfect being exists in reality as well as in the mind. 
The founder of modern philosophy, Rene Descartes defended versions of the ontological argument (Copleston, 1972: 75). Like Anselm, Descartes said that as 'subject' cannot be without its 'predicate' so also the talk about God is impossible without an affirmation of his existence. God's existence therefore is such an integral part of his nature that his existence cannot even be doubted. Descartes begins with the concept of the most perfect being whose attributes such as omnipresence, omniscience, justice, benevolence and so on suggest that God possesses all perfections because an actually existing being or thing possesses more metaphysical power than an imaginary one. Therefore God must exist because actual existence is a necessary attribute or perfection of the most perfect being (Miller, 1995:28).

Lending credence to the discussion, Hartshorne and Malcolm have tried to show that God's existence is either logically necessary or logically impossible, and that, as it has not been shown to be logically impossible, it is logically necessary. Their position is summarized thus:

The very idea of God implied that all beings who are aware of anything must be aware of Him. For he is the all-pervasive, unsurpassable comprehensive being, absent nowhere functioning in and through all things, so internately that in abstraction from him they are non-entity (Copleston, 76).

Leibniz reacted to the questions raised by Descartes' opponents who argued that, the imperfections in the world created by the most perfect being is a contradiction. In his theodicy, Leibniz posited that in spite of all the imperfection in the created order, this is the best possible world. An attempt to remove evils from this world may leave it less than the best; and that in spite of the appearance of evil in this world which should not be traced to God but man, there is still far more good than evil.

\section{The Necessity of Theistic Arguments}

Certain factors were connected to the emergence of some movements that eventually led to the development of critical enquiry in the people. One of such was the Renaissance, a spirit of freedom in thought and action which brought a situation whereby men were no longer content but began to question the teachings, the superstitions and the customs of the past (Southgate, 1938: XVI). In addition was the rise of modern science which weakened the authority of the Church (Russell, 1979: 479). In the seventeenth century, the greatest challenge to the authority of the church resulted from attempts made to explain the structure of the solar system scientifically and at the same time to interpret literally, certain statements in the Bible (New Catholic Encyclopaedia, 1967: 568). The works of Copernicus, an astronomer; Kepler with his three laws of planetary motion; Newton's law of universal gravitation and Galileo Galilei's law of falling bodies - all changed the orientation of the people from their traditional or dogmatic belief to a more logical proof for God's existence.

One of the first philosophers who argued consistently that God does not exist and tried to build his whole philosophy on such an idea is Friedrich Nietzsche, the German philosopher (1844-1900). He sought to deny the whole system of Christian belief. In this regard, he says:

Vast upheavals will happen in the future, as soon as men realize that the structure of Christianity is only based on 
assumptions... I have tried to deny everything (Russell, 1967:9).

Nietzsche is of the opinion that the whole Christian teaching about God is a mere assumption, a wishful thinking because God is dead. The death of God, according to him, means man's liberation because God was an obstacle to man's progress since he imposed 'slave morality' on man (Omoregbe, 125). The idea of slave morality was interpreted as Christian morality which hitherto has prevented man from developing his intelligence and instincts.

The problematic existence of life influenced the work of Nietsche which later resulted to his hypothesis that nothing is sanctimonious about moral values or Christian morality because they have all outlived their usefulness. Hence he recommends nihilism as the only means through which new values that could promote the will to power can be attained (Castell, 1976:235). He is convinced that this is only achievable when men start to re-examine their human situation and stop believing in the existence of God.

Jean - Paul Sartre also emphasizes the need to draw the consequences of atheism 'right to the end'. He remarks as follows:

When we speak of abandonment - a favorite word of

Heidegger - we only mean to say that God does not exist,

and that it is necessary to draw the consequences of his

absence right to the end (Sartre, 1970:26).

Sartre added by describing very vividly the atmosphere in which he was brought up and how 'God' gradually 'died' for him. His existentialism was simply an attempt to take his atheism to its logical conclusion. A.J. Ayer, the English philosopher declares as follows:

I do not believe in God. It seems to me that theists of all kinds

have largely failed to make their concept of a deity intelligible;

to the extent that they have made it, they have given no reason

to think that anything answers it (Ayer, 1966:14).

Ludwig Feuerbach, in his own view maintains that God is no other than an imaginary being (Omoregbe, 117). He sees God as the projected image of human nature. Therefore when man thinks he is worshipping God, he is actually worshipping his own nature in its perfect form.

Similar to Ludwig's submission is the psychological approach of Sigmund Freud who maintains that God is an imaginary being which in reality does not exist. As far as he is concerned, odds of life can lead man in his desperation for security to create for himself 'an imaginary father'. The idea of God therefore resulted from 'childhood neurosis'.

Gaunilo says that the ontological argument has only succeeded in defining God to existence. He illustrates this point by making reference to an Island; that it may be defined but this does not mean that it exists. According to him, since one cannot prove the existence of anything by simply giving a definition, nothing can be defined into existence. Gaunilo then regards Anselm's argument as baseless since he cannot convince the believer that God exists and that it is totally useless to the fool. He further says that Anselm in all his piety is guilty of 'transferring concept into reality' without any concrete evidence.

Another critic of ontological argument is Immanuel Kant who says that the most obvious weakness of the argument is its unjustifiable transfer of the realm of idea to the realm of 
concrete existence. He says further that all Anselm has achieved in doing is the presentation of idea about God which has nothing to do with his existence. To say that God exists is like saying nothing about him since his existence cannot be substantiated with concrete evidence.

\section{African Theistic Perspectives}

This aspect of the discussion deals with African numerous ideas about God. Although past European writers who were ignorant of African belief erroneously raised the question whether the idea of 'Supreme Being', a 'high God' is known to Africans and whether such a God is worshipped in Africa. Bosman among others opined that although Africans believed in a high God, they did not worship Him. In reaction to these cynics, many works have debunked such opinions (Parrinder, 1961:14).

Therefore, African proofs of the reality of God shall be discussed in a following ways:

(a) Argument from the names of God

Contrary to the extreme expressions of people like Westerman, for whom God in Africa is a dues incertus and a dues remoteus (Emefie, 19991: 7), or Ludwig's submission that "the untutored African cannot conceive God" (Idowu, 1962: 30), African names for God depict their understanding of the concept. Few of these names shall be discussed. Olodumare which Idowu extensively elaborated means many things. However, its basic meaning is that God is a Being who possesses superlative qualities, one who is unchanging, constant, permanent and reliable.

Adewale added that he cannot be presented in images neither can people think of confining Him within space because He spreads over the whole extent of earth as depicted by one of his appellations Atererekaiye (Adewale, 1997: 42). His omnipotence is expressed by the Yoruba in statements such as Adun-se bi ohun ti Olodumare se: a soro se bi ohun Olorun ko lowo si"easy to do as that which Olodumare performs; difficult to do as that which Olodumare enables not" (Adewale, 41). To a great extent, this attribute of God among the Yoruba has similarity in the theistic argument of Anselm earlier discussed that God is a being than which no greater can be conceived. A being who is most powerful in heaven and on earth, who is able to do all things, an enabler of all who achieve any ends and who can speak and bring His word to pass without any possibility of failure.

The etymology of other African names reveals their belief in the Supreme Deity. The Igbo believe that Chi (God) although lives in the depth of the sky, yet He is not so distant from His people (Emefie, 47). A correspondence of this belief is seen among the Ashanti of Ghana who state that God is in the sky hence the necessity of daily offerings in pots which are put on the roofs of their huts for the great God of the sky (Parrinder, 1974: 57). No wonder therefore that the Ebira call Him Ohomorihi - "the giver of rain". Owing to their sole dependence on rain for agricultural activities and for the fact that water is needful for life, they assert that the giver of rain is the Supreme God (Yakubu, 2002: 24).

(b) The Personality of God

Behind African beliefs and actions lies a feeling of the existence of something or somebody beyond themselves, a mysterious power which cannot be seen or fully understood but which is at work in the world (McVeigh 1974:9). This means that to Africans, God is not an abstraction but a personal, living and active reality. The Yoruba, for instance, do not see Him 
as a physical being which anybody can see or touch. However, they have a feeling of Him. This inculcates in them a sense of awe, inadequacy, reverence and dependence in the face of the unfathomable mystery of life; and resulted in the worship of God through sacrifice in shrine and altars.

African continent is permeated with countless altars, shrine and sacred places where rituals, offerings, libations and sacrifices and other religious rites are carried out. Some sacrifices are performed directly to God, while others are made through the deities. Rattray's observation that every compound in Ashanti contained an altar to the sky God and frequented by dedicated priests (Parrinder, 15) is not totally different from what obtained among the Yoruba in pre-Christianity era.

Arinze however corroborated the earlier assertion as regards the direct sacrifice to God. $\mathrm{He}$ identified a type of such in Igbo traditional religion called Aja Eze Enu - "sacrifice to God, king of heaven" (Emefie, 52) which is usually made during the harvest season. This is not only common in Igboland but is widely diffused among the Yoruba. In his assessment of African peoples and God, Ocaya submitted thus:

\section{All the frequent rituals and ceremonies are devoid of meaning if they are not centered around God.}

Therefore, African belief in deities does not in anyway portray the polytheistic nature of their religion since they see those deities as means to an end and not end in themselves. God, to them, is one while different religious rites depict different approaches by which he could be accessed.

(c) African Theophoric names

The term "theophoric" comes from the Greek roots "theos" (God) and "phorein" (to bear) and therefore implies "God-bearing". Thus, theophoric name is one which semantically contains the idea of, or reference to, God, the gods or the Divine.

Basically, a name is an expression or reflection of its bearer's essential nature, character, personality or innermost being. However, preponderance of evidences abound that in Africa, names also reveal the connection of a particular community or family with the deities.

In addition to the aforementioned is the fact that apart from names such as Orisabiyi (deity gave birth to this child), Orisagbemi (deity favoured me) and so forth, the Yoruba child also have names such as T'olorunju (God is the priority), T'oluwalase (God has the final say) and Oluwafemi or Olorunfemi (God loves me) as the case may be. Igbo names such as Ngozichukwu (the blessing of God) and Nnaemeka (Father or God has done much) (Awolalu, 1979:36), all suggest African notions of God. The people would not have given their children theophoric names without proper understanding of the attributes of God as well as his disposition towards His creatures.

Commenting on this issue, Obada-Obieh contended that African names are highly significative and pregnant with meanings, carrying the sacramental or covenant signs of their history, culture, tradition and religion among others (Obieh,1998:201). If this assertion is true, then theophoric names can be viewed as indicators of the covenantal relationship between God and the Africans.

(d) Divine Self-disclosure 
The revelation of God from time to time also lends credence to African's belief in His reality. While Christianity describes God's self disclosure as theophany (Adelowo, 2001:103), Eliade describes the manifestation of the sacred with the word 'Hierophany'. Whichever term is used, our concern here is essence of God to communicate or reveal himself to man. Idowu emphasized this fact when he asserts thus;

God has never left Himself without witness anywhere in His world... and that this revelation is not restricted to any particular race or creed... (Idowu, 30 \&31).

Africans identified two cardinal media through which the revelation of God is well articulated. These are the created order and man's inner link with the Supreme Being. Beside the fact that the universe reveals the glorious and majestic works of God, Rudolf Otto describes the occurrence of Numen Praesens in man's experience which transcends his world of ordinariness and generates a sense of awesomeness, self-surrender and eeriness (Adelowo, 102). This situation makes man to be in constant touch with the Divine being, the source of his own being.

(e) Taboos

The other areas where the idea of God can be seen as permeating the African religions and cultures are taboos. Taboos are prohibited actions. African societies have code of conducts, the breaking of which is followed by the supernatural penalty (Awolalu, 212); reasons being that, to Africans, taboos remind them of the presence of the invisible and the supernatural. Without any attempt at a full discussion on this issue, it may be sufficient to say that there are personal or social taboos with religious or cultural significance. They are prescribed code of conduct aimed at protecting the welfare of the society. Prohibition of certain behaviors, actions or food is not to frighten man but to serve as constant reminder of the danger inherent in acting contrary to the accepted norms and practices within a given community. This becomes imperative because in African setting, religion serves as a cohesive force within the society.

\section{Interface between Theistic Argument and African Belief in God}

Some philosophers rejected the theistic arguments on the ground that the arguments defaulted in proving the existence of God. Whatever may be the weaknesses of Anselm's theory, the following semblances seem to have been located in his theological position and African concept of God.

Firstly, the unequalled attributes of God which depict His Almightiness were pointed out. These include God's omnipotence and infinity. This is best expressed in his statement that "God is a being than which nothing greater can be conceived". In a similar way, Africans strongly believe that no other deity or supreme being can be conceived apart from God. The Yoruba's expression "Oba bi Olorun ko si" (there is no God/King like God), articulates this view.

Secondly, Anselm's theistic argument maintains that something which exists only in the mind is distinct from something which exists both in the mind and in reality. In the same vein, African theological position tends towards Anselm's theory. God cannot be merely a possible being, but a being who exists necessarily. Although his existence cannot be substantiated 
with concrete evidence, yet African religious expressions in most cases are outward signs of what transpired in their religious experience, where they encounter the Supreme Being who is at all times active and influences the daily events of life (Ocaya V, 84).

\section{Conclusion}

The whole concept of God can best be described as a mystery. To prove his existence is to limit him to the imagination of man. Hence, the advice of Schleiermacher is very germane that the discourse be better left alone. In addition, this paper shares the view of Stolz who says that the mistakes of most critics of theistic argument is that they see Anselm theory as a philosophical proof of God's existence, rather than a mystical theology which Anselm meant it to be. Karl Barth corroborated this view by interpreting Anselm's argument not as a proof but as an attempt to understand more deeply what is accepted by faith (Evans \& Manis, 2009: $67)$.

\section{References}

Adelowo, E. D. (2001). Methods and Theories of Religion. Ado Ekiti: Olugbenro Press and Publisher.

Adewale, T. (1997). African Beliefs, Science or Superstition. Ibadan: Newton House Publications.

Ado Journal of Religions. (2002). Vol. 1 No. 1.

Awolalu, J. O., \& Dopamu, P. A. (1979). West African Traditional Religion. Ibadan: Onibonoje Press \& Book Industries Nig Ltd.

Boer, H. (1976). A Short History of the Early Church. Ibadan: Daystar Press.

Bolaji, I. (1962). Oludumare: God in Yoruba Belief. Ikeja: Longman Nig. Ltd.

Compleston, F. C. (1972). A History of Medieval Philosophy. London: Methyen \& Co. Ltd.

Emefie, I. (1991). African Religions in Western Conceptual Schemes: The Problem of Interpretation. Jos: Imico Press.

Evans, E. S., \& Zachary M. (2009). Philosophy of Religion (2nd ed.). Illinois: InterVarsity Press.

McVeigh, M. J. (1974). God in Africa. USA: Claudestark Incorporation.

Mepaiyeda, S. M. (1997). Evaluation of the Contemporary Objections to Ontogological Arguments. A Semester paper for M.A. Degree Examinations in Course RES 702, Edo State University.

Mepaiyeda, S. M. (2007). A History and Development of the Anglican Church in Kogi \& Kwara States (1854-1999). Ph.D Thesis in the Department of Religious Studies, University of Ado Ekiti.

Miller, L. (Ed.) (1995). God and Reason: An invitation to Philosophical Theology. New Jersey: Prentice Hall. 


\section{Macrothink

Njinya-Mujinya, L. (Ed.) (1989). The African Mind. Journal of Religion and Philosophy in Africa, 1(1).

Obada-Obieh, J. (1998). Understanding Christian Doctrines in African Context. Lagos: Badapat Publications.

Omoregbe, J. (n. d.). A Philosophical Look at Religion. Lagos: Educational Research and Publications.

Oshitelu, G. A. (2002). A Background to Christian Philosophy. Ibadan: Oputoru Books.

Osunwole, S. A. (1989). Healing in Yoruba Traditional Belief Systems. Ph.D Thesis in the Institute of African Studies, University of Ibadan.

Parrinder, G. (1961). West African Religion. London: Epworth Press. 